\title{
Being Proactive
}

\section{On the Streets in Southeast Nashville}

When I began riding with officers, I naively assumed that they would make stops when motorists clearly violated the law, such as by speeding or running a traffic light. These are what scholars Charles Epp, Steven Maynard-Moody, and Donald Haider-Markel call traffic safety stops. ${ }^{1}$ Drivers who are on the receiving end of them may bemoan their bad luck and get upset, but most motorists accept traffic safety stops as a legitimate use of police power. Motorists leave these stops understanding why they were pulled over, and they tend to accept the accompanying sanction-typically a warning or a ticket-as appropriate. ${ }^{2}$

Officers in Nashville's South Precinct made traffic safety stops occasionally, but they were far more likely to make stops for minor technical violations: expired registration tags, broken taillights, and too-dark window tint. Unlike traffic safety stops, which occur because a motorist has driven recklessly, these stops are called investigatory stops, and they occur because the officer wants to investigate the driver. Rather than target egregious violations, investigatory stops "target people who look suspicious." 3 Unlike traffic safety stops, these types of stops are experienced by motorists as an assault on personal dignity (see chapter 6).

In Southeast Nashville, most vehicle stops were investigatory. They were akin to fishing expeditions; officers used them to check people out. Routine procedures during the stop included running the car's license plate number through the dashboard computer so the officer could determine if the car was stolen, if the registration was current, if the plates matched the vehicle, and if the car had a BOLO (a note indicating that officers should "be on the lookout" for the vehicle because police suspected it had been used for criminal activity). When running a motorist's driver's license number, officers checked if the license was valid, if the picture on 
the license matched the one in the state database, if the driver who had furnished the license was the person pictured, and if the motorist had any outstanding arrest warrants or criminal history. During investigative stops, the officer might ask the motorist additional questions and attempt to search the car, either by asking for permission or by articulating probable cause. ${ }^{4}$

As state legislators were battling over driver's license eligibility in the mid-2ooos, changes were also under way in the Metropolitan Nashville Police Department (MNPD). In 2004, a new MNPD police chief, Ronal Serpas, arrived in Nashville and implemented an operational strategy he called the "accountability-driven leadership model," which used many of the tactics associated with order-maintenance approaches to policing. ${ }^{5}$ A key tenet was the department's expectation that officers should "be proactive." That is, rather than wait for people to call the police for help, the department expected officers to proactively target misdemeanor and noncriminal offenses, positing that doing so would allow officers to identify more serious violations. The department expected officers to target these offenses through the widespread deployment of vehicle stops.

\section{THE LOGIC OF PROACTIVE POLICING}

As early as 1978, police scholars James Q. Wilson and Barbara Boland argued that police should pursue field stops and car checks of "suspicious" people or vehicles to reduce crime. ${ }^{6}$ The authors noted that aggressive patrol dictated that officers maximize "the number of interventions in and observations of the community." They suggested that an aggressive patrol strategy could be achieved through recruitment, training, and incentive systems that "encourage them [officers] to follow the intended strategy." In 1982, James Q. Wilson and George Kelling introduced the "broken windows" theory, which asserted that minor forms of disorder-such as panhandling, public intoxication, prostitution, littering, and broken windowsgenerate more serious crime in neighborhoods. ${ }^{9}$ According to their theory, police could reduce crime by cracking down on minor violations in high-crime neighborhoods. A number of studies in the 1990 os found that police "crackdowns"-targeted enforcement of specific (or all) offenses through pedestrian and vehicle stops-are effective at reducing crime and seizing contraband. ${ }^{10}$ The New York City Police Department is famous (or infamous) for its deployment of stop-and-frisk tactics where officers stopped, questioned, and searched a staggering number of minority pedestrians to check them for warrants, weapons, and drug possession. ${ }^{11}$

The Supreme Court gives police an extraordinarily amount of leeway regarding how they conduct stops. Virtually any legal violation, no matter how minor, can be used to justify a stop, and officers may use these stops to identify more serious crimes. ${ }^{12}$ Officers may also search vehicles and occupants if it is necessary for "officer safety" or if officers have "reasonable suspicion" of criminal activity. Indeed, 
even if the officer stops a car on the basis of a misunderstanding of the legal statute, the stop does not violate the Fourth Amendment as long as the officer's mistake is "reasonable."13 As a result, police officers may stop, question, temporarily detain, and search motorists with little evidence of wrongdoing, so long as they can articulate a plausible reason for doing so. ${ }^{14}$

In their book Pulled Over, Charles Epp, Steven Maynard-Moody, and Donald Haider-Markel argue that investigative police stops became popular in the 199os, as articles lauding the tactic were published in law enforcement trade publications and as information regarding how to conduct investigative stops formed part of policing training manuals. ${ }^{15}$ These publications recommended that officers use vehicle stops as a pretext to investigate unrelated and more serious criminal offenses and offered tips so that officers could stop cars effectively. Over time, investigative police stops became an institutionalized practice, unquestioningly accepted by agencies and officers as the "right" way to police. ${ }^{16}$

MNPD police chief Serpas considered investigative police stops essential to proactive policing. He hoped that officers would take initiative to solve problems, rather than wait for people to call the police for service. In an interview with me, he described his definition of "proactive policing" and explained why he believed the practice was effective:

Proactive policing, from my point of view, essentially boils down to this, if you are not on a directed mission for some reason, either answering calls for service or on your way to the lockup or on your way to testify in court or anything that you're being told to do. Proactive would be, let me get out of this car and walk around this neighborhood a little bit and see if I can get to know some people, let me stop by this business at 2:00 a.m. and rattle their doors and see if their doors are locked. ... Proactive is doing something other than what's being directed.... We are going to stop vehicles without breaking the law, we are going to interview people without violating their rights, we are going to answer calls as quickly as we can, we are going to do proactive work. Well, I know there's warrants out that I need to serve on this street, so let me go check on those warrants. That's proactive. I'm doing something beyond being told by the radio. Well, there's a car that's speeding through this neighborhood, and that's against the law. Let me go stop this car and see what's going on.

According to Serpas, a significant proportion of the department's arrests stemmed from vehicle stops. He raised his right hand and began counting on his fingers as he listed the benefits of aggressive traffic enforcement, from one to three:

One, you have lighted up police service in the neighborhood. Two, you can reduce collision and injuries. And three, you can do an awful lot about crime. Criminals carry guns in cars, and they go from place to place with their guns in their car. We're routinely pulling illegal weapons out of people's cars all the time. 
FIGURE 1. Traffic stops per year made by Metropolitan Nashville Police Department, 2003-12. source: Metropolitan Nashville Police Department Crime Analysis Publications.

At every turn, police administrators spoke with one another, and with rankand-file officers, about the importance of being proactive and getting their numbers up. Officers meticulously documented their policing activities on a log that they turned in to their superiors during "mail drop." These statistics were compiled and reviewed to identify how changes in enforcement were associated with changes in crime. Every week, dozens of police administrators convened at a Compstat meeting to review crime trends and enforcement activities across the city's precincts. At meetings, supervisors and precinct commanders explained week-to-week upticks in crime or reductions in vehicle stops, providing plans for improvement.

As a result of the department's shifting bureaucratic priorities and incentives, officers in Nashville made a staggering number of vehicle stops (figure 1). For example, in 2003, Metro officers made a little over 125,000 stops a year-an average number of stops for cities of its size. However, after Chief Serpas joined the department and institutionalized new policing priorities, vehicle stops skyrocketed. By 2007 , for example, vehicle stops had doubled. Metro police averaged about five thousand traffic stops a week, over twice the average number of stops in similarly sized cities. ${ }^{17}$ With the exceptions of 2007 and 2009, when vehicle stops fell modestly from the year before, this figure demonstrates the department's dramatic escalation. 


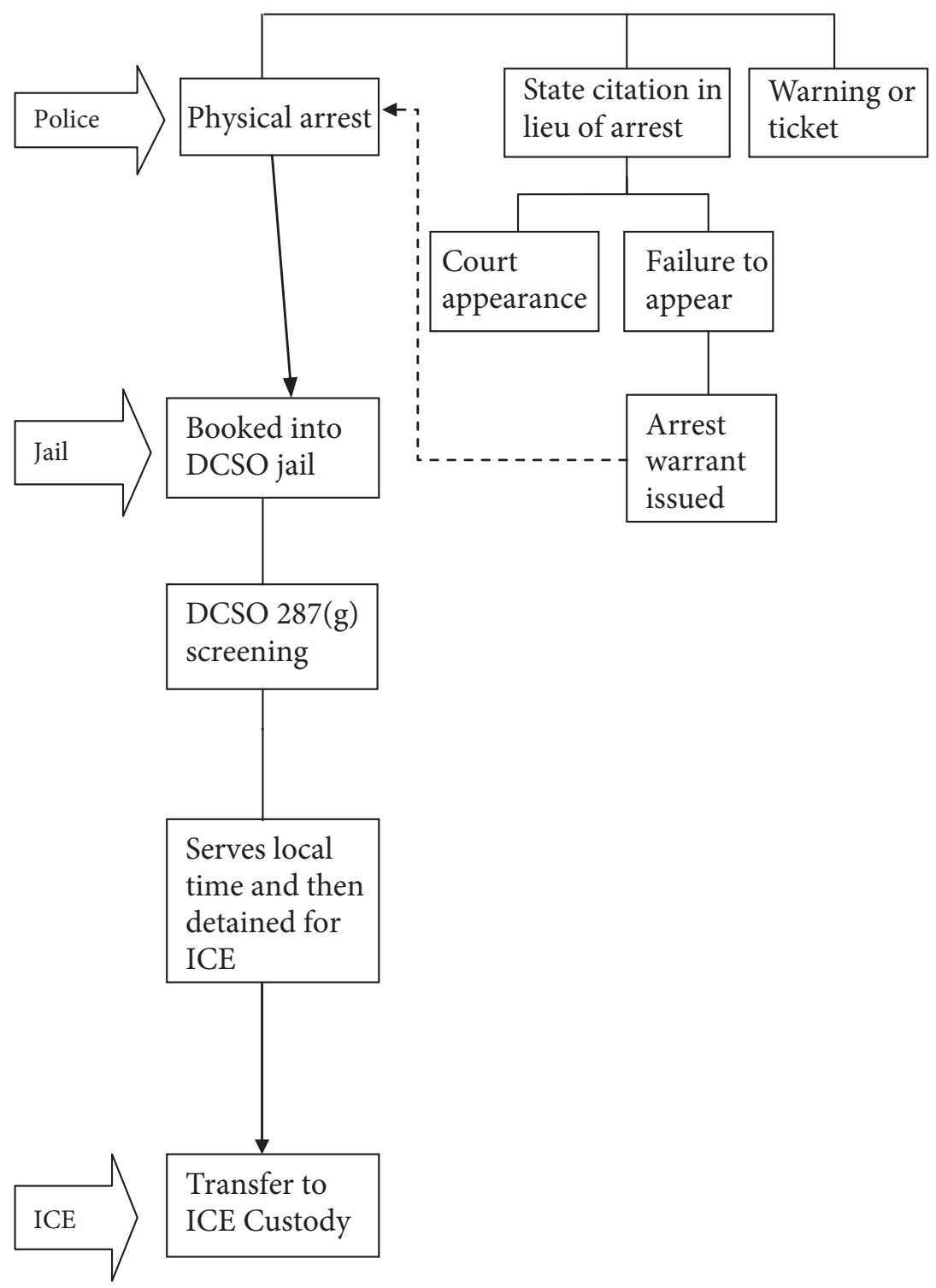

FIGURE 2. Possible outcomes of police traffic stops for unauthorized immigrants in Davidson County. 
Officers made investigative traffic stops because the department expected them to. A department priority, vehicle stops were fundamental to what it meant to be a good patrol officer. Although aggressive policing tactics form part of the occupational culture of policing, these institutionalized practices have consequences. While intentionally targeting minority drivers for scrutiny is illegal, encouraging officers to make large numbers of stops for minor technical infractions is not. In Southeast Nashville, the sheer number of vehicle stops that officers made ensured that officers would stop Latino motorists. These stops inevitably put Latino motorists at risk of arrest (and deportation) given unauthorized immigrants' ineligibility for state-issued driver's license and identification cards (figure 2).

\section{INCENTIVES}

Making stops was built into the department's incentive structure. To meet the department's expectations and to climb up the ranks, officers had to use their time between service calls to engage in officer-initiated activities. Doing so was in their best interest. The more productive officers received better evaluations and were more likely to have their preferences accommodated when they requested new shifts, assignments, or promotions. In contrast, unproductive officers received the less desirable shifts, assignments, and equipment. The department did not have official quotas, but it did have expectations, and officers knew when they were not measuring up.

Rookie officers tended to unquestioningly accept the department's mission. They did not know any other way to police; the department's philosophy made sense to them. These officers reinforced the department's priorities by making stops a frequent topic of conversation and by good-naturedly teasing one another if their stats were down. They described being proactive as "earning their paycheck." In their view, officers who were not proactive were lazy. For example, Officer Thompson credited his "good days off" (Sunday and Monday) to his productivity. He told me, proudly, that he makes between sixty and sixty-five vehicle stops a month.

When I asked another officer how many stops he thought that the department expected, he responded, "Honestly, I have no idea, but everyone should be able to get three or four stops a night without much of a problem. I want to do flex so I try to do a lot." The flex team was a proactive unit of officers in a precinct who worked together to saturate particular hot spots (geographic locations associated with crime) with a goal of disrupting criminal behavior. Unlike patrol officers, flex officers did not answer calls for service, did not clear traffic accidents, and were not dispatched to take reports. They often drove in unmarked cars, with some officers in plainclothes and others in uniform. Since they spent all their time doing proactive enforcement, flex officers tended to make the most arrests and confiscations. 
For young officers who were itching to be part of the action, being on flex was desirable, and showing that one could consistently put up good numbers was key to winning a flex spot.

While most patrol cars were assigned to patrol and answer calls in particular zones, sometimes officers were assigned to "enforcement only" Officers assigned to enforcement did not have to answer calls and instead moved from one vehicle stop to another. These were also desirable posts, as officers assigned to enforcement made more stops than officers who had to respond to calls.

It is worth noting that not all officers embraced the department's emphasis on proactivity. Some disliked making traffic stops because it required no skill; it was like shooting fish in a barrel. This dragnet approach to finding violations made each police encounter less productive. "I used to make one or two arrests for every ten traffic stops, now I probably make an arrest every twenty traffic stops," an officer said. "You're pushing the numbers up because you're making stops and trying to find illegal activity," another said in disgust. Veteran officers complained bitterly about the department's shift in priorities; they felt that their seniority and experience went unrewarded. They described feeling stressed and resented competing with young officers for days off and preferred shifts. One officer believed that the department had taken away his assigned patrol car to punish him for low productivity. An officer with over twenty years on patrol complained, saying, "It used to be that it [job performance] was how quick can you answer your calls, and do you answer your own calls. ... Now, by making so many stops, people aren't even available when the calls come out. Back then, we never would have let someone else take calls in our zone! No. But the chief has said he doesn't mind, that these stops matter, so calls can wait. Now people have to wait when they make calls because all the officers are out on traffic stops."

\section{CALLS FOR SERVICE}

While the department prioritized proactive enforcement, officers could not be proactive all the time. In fact, a great deal of police work involves sitting around and doing tasks that are not particularly exciting: answering routine calls for service, taking reports, filling out paperwork, and clearing traffic accidents. Officers on patrol balanced several responsibilities. While they had instructions from their superiors to be proactive and make traffic stops, they also had to respond to calls for service.

Operators at the Emergency Communications Center assigned each service call the number one, two, or three to designate the level of urgency with which officers should respond. "Code one" indicated that the officer should proceed to the location when available; these calls were not urgent. The officer might make traffic stops along the way or be redirected to a higher priority call. "Code two" 
indicated that the officer should proceed immediately to the location, but without lights and sirens. "Code three" calls were for emergencies and indicated that the officer should ride with lights and sirens and arrive as quickly as possible. Officers were dispatched to respond to calls in their zones, but if the officer assigned to the zone was unavailable to answer a high-priority call, dispatch might pull an officer from a nearby zone to respond.

When an officer was on a call, the officer was doing police work, but he or she was not being proactive. As a result, there was a tension between answering calls for service and being proactive. For example, after wrapping up a call about a domestic disturbance between roommates, three officers and I stood in the parking lot before returning to patrol. It was just after 9:0o p.m. on a Friday night. The call took over an hour to resolve. "I didn't make any stops tonight," Officer Kerry said glumly. "I was going from call to call to call. It just didn't seem right to make stops when there were so many calls." The other officers murmured their agreement and nodded.

Officers acknowledged that there were strategies to minimize answering calls. For example, officers might "ride out a stop" so that they were unavailable to be dispatched to a low priority call. One officer was notorious for being "checked out" until he heard a call that he wanted to take. Then he would check back in. Colleagues did not appreciate this behavior because they had to pick up the slack. I asked how they balanced answering calls and making stops, and an officer responded, "I try to get in stops when I'm on my way to stuff, but you have to be careful. You don't want to be that guy who left your buddy hanging on a call because you want to pad your stats and then something goes wrong. You don't want to be that guy."

Once a city dispatcher indicated that a caller required police assistance, an officer was obligated to answer the call, even when experience dictated that doing so was pointless. People call the police for astonishingly trivial reasons. They call because their neighbor's music is too loud, because a kid is throwing rocks that land on their lawn, because they are upset or angry at their roommate, their friend, their partner, or spouse.

Many times, there is nothing for an officer to do except document the caller's complaint and attempt to resolve the disagreement. If the officer hears loud music, the officer will knock on the neighbor's door and request that the neighbor lowers the volume. The officer will tell the kid not to throw rocks and will tell the caller that a kid throwing rocks requires police intervention only if the kid is obviously trying to hurt someone. In cases of nonviolent interpersonal disputes, officers will allow both parties to air their grievances and suggest that one of the parties take a walk or stay with a friend to "cool off."

Answering calls can be frustrating. An anonymous caller will report that a person is screaming, but the officer never finds a screaming person by the time he or 
she arrives at the indicated location. The alarm company will call the police about a triggered security alarm, but officers will arrive and discover that the building is secure (false alarm) or that the assailant is long gone. For each of these calls, the officer must stop what he or she is doing, drive to the appropriate location, and attempt to resolve issues that usually have no legal resolution. Still, each of these calls generates additional paperwork that the officer must complete.

Thus officers are not particularly excited about answering calls for service. They take a long time, and since many calls are not about actual crimes, they force officers to respond as social workers instead of law enforcement. Often, neither the officer nor the caller will be satisfied with the officer's response.

Still, while officers did not respond to calls eagerly, when they arrived they behaved professionally and resolved situations as best as they could. For example, called about a fight at an apartment, we arrived to find out what had happened. An upset middle-aged man complained bitterly that his girlfriend had kicked him out of her car on another side of town, forcing him to walk home three or four miles after she found texts from another woman on his phone. He was sweating and his face was red. The walk had taken him over an hour. As he spoke, the man took a small pair of scissors out of his pocket, and accused his girlfriend of having used them to attack him. He pointed to a spot on his ear, where he had a small nick that looked a lot like a paper cut.

"Why don't you let me hold on to those scissors?" asked Officer Kerns smoothly, before asking the man to continue.

Something about the scene-the small red-faced man whose girlfriend had been so upset she forced him to walk home, the scissor attack that had resulted in a paper cut, and the man's righteous indignation as the wronged party-struck me as extremely funny. In fact, I worried that I might explode with laughter at any second.

The man was quite short, so Officer Kerns looked over the man's head and we locked eyes. Kerns did not say a word, but his eyes twinkled, and when the man looked away Kerns winked at me. Slowly, I turned around and stared at the wall, hoping that it would help stifle the giggles I could feel building up inside of me. Finally, I scurried outside for a breather. In contrast, Officer Kerns maintained his composure, never indicating to either party that he found the call amusing (although we cracked a few jokes about it later in the shift). Kerns documented the dispute but left without arresting anyone.

When we got two calls one afternoon about a child with a sword, we rode to the block with lights and sirens since a child's welfare was at stake. None of us expected to find a kid with a real sword, since one does not often stumble upon a sword-wielding child on a city sidewalk. We figured it was fake and joked that we should all be very careful since there was someone with a weapon on the loose. After we tracked down the person who had called the police, we knocked on the door where the child allegedly lived. After talking to his parents, we learned that 
he had, indeed, been playing with a real sword. The child's parents explained that the sword was used for history reenactments and was not sharp. Officers kindly asked the kid's parents not to let their child play with weapons.

Once we spent almost two hours at an apartment after an eighteen-year-old nonverbal autistic young man assaulted his home health aide. When we arrived, one side of the health aide's cheek was starting to swell. The young man was sitting on the couch looking at a book. The fire department was also there. Neither the police department nor the fire department medics could figure out who was empowered to make medical decisions for the young man and whether a bureaucratic response was even appropriate. Officer Hamilton refused to take him into custody, saying, "He doesn't need to be in jail. He won't last and they won't know what to do with him." After calling a mobile crisis unit and learning that the young man did not qualify for their intervention, the fire department medics decided to take the young man to a hospital where he had previously received treatment, hoping the hospital could help figure out who had previously attended to the young man.

Answering calls required that officers communicate with a wide cross section of the city's residents. Sometimes this was challenging. Called about loud yelling in an apartment, we arrived at the home of a family who spoke a Middle Eastern language we could not identify. We flagged down two residents who were walking by to ask for help. The neighbors, a father and his teenage daughter, were reluctant to stop and indicated they had no desire to be involved. We asked if they might identify what language the family was speaking so we could try to find a translator, and finally they agreed to help out. What ensued was similar to a game of Telephone, in which a message is relayed through a line of people until the last player announces the message to the group. The young woman's father spoke to the family in one language, he translated to his daughter in another language, and she relayed the information to us in English. She could not communicate with the family directly because she did not speak that particular dialect, and while her father did, he did not speak English. Through this chain, we learned that this young family had only recently arrived in Nashville and were overwhelmed. The young mother had three children, and the youngest, four years old, had behavioral issues. As we stood there, he yelled, threw objects, and jumped off furniture. Officers looked at the boy and decided there was no reason to intervene at the moment. We thanked the neighborhood translators for assistance, filled out a report, and left. As we walked away, the officers discussed kicking the report to another division so that officers could follow up later.

\section{HOW TO BE PROACTIVE}

Patrol officers knew that they were supposed to do more than just respond to service calls. Their stats were a frequent topic of conversation among their colleagues 
and superiors. They were habitually reminded to be proactive while on patrol. To meet the department's expectations, patrol officers engaged in numerous "proactive" activities that intruded on the lives of Nashville residents. This behavior did not stop when officers answered calls. Officers used calls for service as opportunities to ask for identification cards (or names and dates of birth) for every person with whom they came into contact. Thus even calls for service became interactions in which officers could identify people to determine if they were "wanted."

MNPD officers could "be proactive" in a number of ways. On patrol with officers, I quickly learned some tricks of the trade. Passing through the parking lot of an apartment complex was an "apartment check." Chatting with residents through the window of a squad car, or stopping someone on foot to ask for identification was a "community contact." Even buying a soda at a convenience store or eating at a restaurant for lunch could be "proactive" if the officer designated the stop as a "business check." Of course, the prized proactive activity was the traffic stop.

When shifts were busy, officers had to squeeze in stops between their other activities. For example, an officer might try find a stop on his way to a low-priority call. Or an officer might choose to stay "checked out" on a service call or a meal break until the officer found a traffic stop. This allowed the officer to check back in on a stop and ensured that he or she would not be immediately dispatched to the next call.

To meet the department's expectations, officers were constantly on the lookout for minor violations that would allow them to legally pull over vehicles. For example, as we drove, Thompson had his left hand on the steering wheel and his right hand poised above the computer keyboard in the patrol car. He ran license plate numbers frequently, in case he discovered that the car was stolen or registered to someone with a warrant. While none of his inquiries generated hits, he finally spotted someone with a malfunctioning brake light out and pulled it over. In general, officers pulled over more motorists for equipment failures than for moving violations.

When I asked an officer about this preference, he explained:

Well, speeding is harder because you have to prove it, and what are you going to say? I paced him for three counts? You can't necessarily prove that. If we say we initially pulled them over for something technical, there's no disputing that.

Since officers had to generate stops to show that they were being productive, most officers were not choosy about who they pulled over. Calls for service were unpredictable: a call could take anywhere from several minutes to several hours. Officers were never sure if and when they would have time for traffic enforcement, so they had to fit enforcement into whatever time they had available. That is, if they had time to make a stop and they spotted one, they would pull the car over. 
In contrast, they might ignore violations if they were busy running from one call to the next or needed to transfer an arrestee downtown. One night near the end of the shift, Officer Henderson considered pulling someone over and decided against it because he did not want to make a stop that might delay his return home.

Ideally, an officer spotted a violation and made a stop. In practice, an officer might see a car that he or she wanted to pull over before the officer had identified a reason to do so. More than one officer mentioned that it was almost always possible to make a stop, given the innumerable provisions of the Tennessee Code. Officers must always be able to articulate a legitimate reason for making a stop, but they do not necessarily have to be right.

Indeed, I saw officers pull people over for suspected tint violations because the officer "believed" that the window tint was too dark. I never saw an officer use a tint meter to determine if the tint was actually too dark or issue a ticket for a tint violation. This signaled that officers did not make these stops because they cared about window tint. The stops were a pretext. Officers made them to generate contacts with civilians to try to identify additional violations. The law generally permitted this approach to policing, and the department believed it was good practice.

In addition, officers pulled people over for a number of violations that I never knew existed. In Tennessee, it is illegal to operate one's windshield wipers without the vehicle's headlights on. ${ }^{18}$ This means that any time it rains and a car is using its wipers, an officer can pull over the motorist if the headlights are off. Some motorists like to place a tinted cover over their license plate to protect it; this too, is illegal. Tennessee state law prohibits any tinted materials over the plate, even if the tint does not obstruct the officer's view of the plate. ${ }^{19}$ There are times when it is impossible to avoid violating this tint law. For example, a new car owner might have a temporary license plate, made of paper, hung up with tape in the car's back window until the permanent plates arrive. If the car's back window is tinted (as many are), the driver has violated the prohibition against tint covering the license plate.

Occasionally, officers attempted to enlist me in the relentless quest for stops. "Tell me if you see anything suspicious," an officer said, indicating we could pull over a car of my choice. They instructed me to look out for broken taillights and faulty blinkers. When an officer asked me to confirm his suspicion that a driver was not wearing a seat belt, I answered vaguely and uncertainly, "Hmmm .... I'm not sure." Partly this was because I did not want my input to sway officers' decisions one way or another. I certainly did not want to be responsible for a traffic stop that might result in someone's arrest. Officers were so keenly aware of potential violations that I never spotted a violation before the officer did. In fact, when officers asked me if I saw anything, I explained apologetically that long hours in 
front of the computer had ruined my vision. I am incredibly nearsighted. This is true. I do not see well, and I chose not to try very hard.

\section{PUSHING THE STOP}

After the officer initiated a vehicle stop, sometimes he or she would try to "push the stop," taking additional steps to investigate the driver and vehicle. Research shows that police consistently subject minorities to more intrusions than white motorists, because investigative stops encourage officers to activate embedded racial stereotypes about what kinds of people are "suspicious." ${ }^{20}$ Indeed, a few times while we were on patrol, officers voiced suspicions about young Latino men that hinged on whether they believed Latino men were workers or possible gang members. Some officers believed that they could make these determinations on sight because as officers they had a "sixth sense" or "hunch" about who might be involved in criminal activity.

For example, I was on a ride-along with Officer Smith on a Saturday night when Smith spotted a maroon Honda Accord. The car immediately made him suspicious because of the number of passengers. "Where you going?" he asked aloud, craning his neck to look at the car as it passed him going the opposite direction. Smith peered up at the rearview mirror and quickly made a U-turn across a double yellow line, calling the vehicle's license plate number over the radio. An officer responded, saying that the car sounded like a "BOLO" (be on the lookout) vehicle that was suspected to have been used in a robbery earlier that week. Now Smith was right behind the car. "Are they wearing seat belts?" he asked me. Before I answered, he flashed his lights and sirens, signaling the car to pull over. "Why are you pulling them over?" I asked.

"Uh-tint violation," he responded, in a distracted voice.

The car pulled into the parking lot of a large shopping center and stopped. The stores were closed, and the parking lot was empty. Officer Smith got out of the car and approached the driver cautiously, peering through the car's windows as he approached the driver. A few moments later, he returned to the patrol car with the driver's license. Two additional officers arrived. After quickly conferring with Smith, each officer approached a passenger to request identification. One passenger handed over a Tennessee ID. The other did not have one and gave the officer his name and birthday.

The officers punched the teenagers' names into their respective computers and got no hits. Undeterred, they huddled and decided to ask for consent to search the car. Smith approached the driver and asked casually, "Do you mind if we take a look inside your vehicle?"

The passenger raised his eyebrows in surprise and paused. He seemed to be weighing his options. "Sure," he said reluctantly. He opened the door and walked away from the car slowly. 
"Just have a seat right there," Smith said, pointing to a spot on the pavement. The young man sat down. I stood close by, surveying the scene. He glanced at me, sizing me up. Then he spoke.

"Hablas español?" he asked me.

I was surprised to hear him speak Spanish. It had not been obvious to me that he was Latino. I responded, also in Spanish, saying, "Of course."

"You with them?" he asked, gesturing toward the officers holding flashlights and rifling through his trunk and back seat.

"I'm riding with them-not a cop," I answered. "I'm interested in how they treat Latinos."

"How do you think?" he said, looking toward the flashing blue lights of his patrol car and giving a sarcastic chuckle. "I'm so fucking tired of this," he continued in Spanish. He had been pulled over and searched before. He was frustrated by the continuous intrusions and by the officers' assumptions that he had done something wrong. A few minutes later, the officers returned and told him he could leave. He looked at me as if to say, "See? I told you."

On another evening, a different officer (Brady) and I were on our way back to the police precinct when we saw a white sports utility vehicle roll through a stop sign. Brady immediately flashed his lights and pulled the car over.

After approaching the driver and arriving at the window, Brady motioned for me to come closer. "Ask him for his license and registration," Brady told me.

Before translating, I paused to tell the driver that I was not an officer but that I would be helping the officer with translation. I asked for his license and registration.

The driver, a Latino man wearing a white ribbed tank top, told me that he did not have a license. His eyes darted back and forth nervously and he gripped the steering wheel tightly. Knowing that the officer would want more information, I asked the driver for any form of identification - a passport, a matrícula - anything. He shook his head.

"No tengo nada" (I don't have anything).

I relayed this information to Brady, who promptly asked the young man to get out of the car. The man complied and stepped to the curb. Officer Brady patted him down outside his clothing for weapons but found nothing. He noticed that the man's belt buckle was emblazoned with the letter $M$.

"Ask him if he's in a gang-is he in MS?" the officer asked, accusingly, mentioning a well-known Salvadoran gang.

I dutifully translated: "He wants to know if you're a member of a gang-La Mara?"

The young man shook his head.

The officer's questions and assumptions struck me as problematic. "Is being in a gang illegal?" I asked, as innocently as possible. 
The officer responded that being in a gang was not illegal but that he was trying to decide whether he should arrest the man for driving without a license, since he did not have ID.

The young man turned to me, and pleaded, "Dile que no me arreste. Dile que no me arreste." (Tell him not to arrest me. Tell him not to arrest me.)

I turned to the officer to relay the message. "He asks . . . that you don't arrest him."

The officer stood there looking annoyed, shifting his weight from one leg to the other as he weighed his options. He looked at his watch. I knew that making an arrest could take a few hours, given the distance to central booking and the paperwork requirements. Even issuing a misdemeanor state citation could delay our return to the station by twenty minutes. Ultimately, Hansen's desire to go home won out over his instinct to make an arrest. He cut the man loose. On our drive to the precinct, he lamented not pressing the young man for additional questions about his possible gang involvement.

\section{THE UNCERTAINTY OF IDENTITY}

The first thing an officer does when encountering a civilian-whether answering a call, taking a report, or stopping a vehicle-is request photo identification. To the officer, this is an unproblematic request; establishing a person's identity is central to police work. "We really have to guard against fake ID schemes and things of that nature going on," an officer explained. In fact, officers shared stories with one another about "getting burned" on an identification or making mistakes. For example, an officer vividly described misidentifying a person a decade earlier, when he was a rookie officer. He issued a misdemeanor state citation to a woman who had no identification, thinking he was giving her a break. Instead of providing her own information, however, she claimed to be her cousin. Not surprisingly, neither the woman nor her cousin showed up in court. Police picked up the cousin on a warrant, and, upon booking, deputies saw that the prints on the paper citation did not match. The officer was terribly embarrassed and was careful to not repeat his mistake. "You learn your lesson," he said.

Establishing a person's identity allows officers to determine if the person poses a threat to community safety, if the person is wanted by any jurisdiction, or if the person has some relevant criminal history that the officer should know about. ${ }^{21}$ The "gold standard" of identification is a state-issued driver's license. Officers can verify that state-issued driver's licenses and identification documents are valid by looking up the card on their computer. They can compare the picture on the card and the computer to the person in front of them and feel with certainty that they have established a person's identity. When people do not exist in the state's documentation scheme-as is the case for 
many unauthorized immigrants-officers have discretion to establish identity however they see fit.

Nikolas Rose coined the phrase "securitization of identity" to argue that demonstrating one's legitimate identity is a prerequisite for exercising freedom. ${ }^{22}$ Indeed, in many countries, national identification cards are a mechanism that allows nation-states to sort citizens from noncitizens, excluding nonmembers from advantages for which they are not eligible. ${ }^{23}$ Individuals depend on states to legitimize their legal identity, but a state must unambiguously identify its members so it can develop laws to govern them. ${ }^{24}$ Identification documents play "a crucial role in modern states' efforts to generate and sustain their 'embrace' of individuals." ${ }^{25}$ Legal identification is crucial for access to rights and services. The wrong kind of ID, or no ID at all, can impinge on one's opportunity to work and move freely through society.

Uncertainty about identity is at the core of Latino immigrants' vulnerability to arrest. Department administrators knew that the standards their officers used to establish identity were an important issue for Nashville's Latino immigrant community. As a result, they tended to describe scenarios in which officers worked exhaustively to make a positive identification. According to the commander of the South Precinct, police officers were "very willing" to find "everything they can" to make a positive identification. He explained:

The officer, obviously what we hope to see is a valid DL with your picture and everything. If that's not the case, then the officer has several things at his or her disposal. At the end of the day in that situation the officer has to feel 100 percent confident that they've been able to properly identify who I've got, and how I'm, who I'm dealing with. So that's really the ultimate goal is to make sure that I've established the fact that the person I'm actually dealing with is this person by name and DOB [date of birth] and things of that nature. ... The officer can, there's not really a definable list of how an officer, what he uses to determine if that's the person he has or not. It can be several different things. Picture IDs are always good. Work IDs with a picture. An NES [Nashville Electric Service] statement with a name. Maybe a family member that shows up and can verify who the person is, so it's a mixture or combination of one thing or ten things. Whatever the officer can build to be able to say, this is who I've got, this is who I'm dealing with here.

Thus the department's laissez-faire identity policy empowered officers to issue misdemeanor citations, but it did not require that they do so. Chief Serpas emphasized that he expected police officers to rely on their professional experience and expertise when deciding whether to cite or arrest. That is, he believed that officers' investigative training entitled them to judge whether documents were valid. He explained:

Ultimately, at the end of the day, we rely on police officers, who are investigators. They're trained to be investigators. We rely on them to make a value judgment and 
then explain it in their document. That's all we ask them to do. And I've got examples that I know of where an officer had what appeared to be valid information and said, "I'm not gonna do the misdemeanor arrest." But likewise, if the officer cannot articulate why he or she is comfortable telling the court that I know so-and-so is gonna show up, then they end up having to do a physical arrest. So it's up to them to articulate.

The police chief's statement is instructive because it demonstrates the standards to which the department held officers. The chief did not say he expected officers to identify documents correctly; he said he expected officers to make a "value judgment" and defend their decisions. That is, the ability to articulate one's decision superseded the need to be correct in one's assessment.

It is also worth mentioning that Chief Serpas's statement is a misrepresentation of Tennessee's state citation statute. The chief indicates that officers may conduct physical arrests when they cannot articulate they are "comfortable" that the suspect will appear in court. The Tennessee statute, however, does not require that officers articulate an expectation that suspected misdemeanants will show up in court as a condition of receiving a state citation. Rather, the law states that misdemeanor state citations should be issued when "there is no reason to believe the suspected misdemeanant will not appear as required by law." ${ }^{26}$ These are not the same. The chief's statement suggests that officers must believe (or articulate a belief) that the suspected misdemeanant will show up in court; the law directs officers to give citations as long there is no reason to believe that the suspected misdemeanant will not appear.

What these statements make clear is that, above all else, the department's expectations regarding how to establish identity were flexible-producing variable results and implications. While officers could use a variety of documents to establish a person's identity, they could also decide that these documents did not constitute sufficient proof if it "didn't feel quite right." The department suggested that officers needed to feel "comfortable" and "certain" that they knew the identity of the person in question. Officers could deny someone their physical liberty with the mere assertion that the person might not show up for their court date.

Without a clear department policy to guide their behavior, police responses to misdemeanor driving offenses were highly variable. That is, facing identical circumstances, one officer might issue a misdemeanor state citation and another might decide to make a physical arrest. Officer Moreno, a longtime officer who ran a community policing program called El Protector (see chapter 4), explained that the decision to arrest depends on the officer. "Well, uh-it could be based on experience. ... The officer is probably gonna be reluctant to accept something that doesn't, that doesn't feel quite right. It depends. It depends on the officer," he said. Officers' decisions about the legitimacy of identity documents were important because this determination affected whether suspected misdemeanants were 
arrested and taken to the Davidson County Jail (and screened for immigration violations through the $287(\mathrm{~g})$ program) or released with a citation and a notice to appear in court. On patrol, officers weighed multiple considerations-the law, productivity, and their own sense of justice-when deciding how to respond to Latinos who drove outside the law.

\section{THE HIERARCHY OF DOCUMENTS}

Although we often describe immigrants as "undocumented," most immigrants have some form of identification and documentation, just not the ones that grant them legitimacy in the eyes of the state. Anthropologist Nicolas De Genova argues that US immigration laws are designed not to exclude unauthorized immigrants, but to socially include them with subordinate status and "under imposed conditions of protracted vulnerability." ${ }^{27}$ The policies and practices dictating whether documents confer driving privileges and proof of identity provide an illustrative example of this subordinate inclusion.

By the time I conducted my fieldwork all the driver's licenses and certificates for driving that had been legally issued to unauthorized immigrants in the state of Tennessee were expired. When police encountered motorists with expired documents, officers were authorized to confiscate them, making it impossible for motorists to identify themselves upon future encounters with law enforcement.

Foreign driver's licenses also did not protect motorists from sanction. According to Tennessee state law, the state recognizes driver licenses issued in other countries, but only under certain conditions. ${ }^{28}$ Technically, the law allows noncitizen visitors with valid passports to drive with foreign driver's licenses. In contrast, noncitizen residents must apply for Tennessee documents within thirty days of establishing residency. Thus police officers may reject foreign driver's licenses if they determine the motorist is a resident (rather than a visitor) or if the motorist does not have a passport.

Consular identification cards are also not necessarily "satisfactory" identification. For over a hundred years, the Mexican government has issued an identification card called the matrícula consular to Mexican citizens living abroad. Given the importance of establishing identity and immigrants' ineligibility for many USissued identity documents, the cards are even more ubiquitous now. A number of other foreign governments also issue identity cards to their residents living in the United States. Still, the cards are not without controversy. Critics resent that matrículas make it easier for immigrants to secure services in the United States. ${ }^{29}$ Officials with the DOJ and FBI have also argued that the cards pose a threat to national security. ${ }^{30}$ Speaking specifically about Mexican consular identification cards before the House Judiciary Subcommittee on Immigration and Border Security, FBI official Steven McCraw testified that the cards could be 
obtained under any name and were easily counterfeited. McCraw also asserted that non-Mexican foreign nationals had been able to obtain Mexican matrículas, creating fictitious identities that enabled them to move freely throughout the country without triggering the attention of law enforcement.

In response to these concerns, the Mexican consulate began issuing a "highsecurity" matrícula with more security features and more documentation requirements in 2002. Mexican citizens must apply for matrículas in person and must present a variety of documents to prove their citizenship, identity, and US place of residence. The cards have a number of security features designed to make them difficult to fraudulently replicate and easy to authenticate for law enforcement agencies. ${ }^{31}$

Across the country, the issue of whether to accept consular identification cards is highly contentious. While many local and county governments, financial institutions, and law enforcement agencies accept matrículas as a matter of policy, others do not..$^{22}$ In Nashville, the cards are accepted at financial institutions and state benefit offices, but they are not officially accepted by the MNPD. The chief explained:

Chief: The matrícula - we recognize it, but we're not going to be able to value it the same as the issuing document of one of the fifty states because that would turn into, well, what do we tell a police officer that gets something from Poland? What do we tell a police officer if they see something from the Soviet States? We don't know the value of how the matrícula was created. Now, the matrícula people tell us how they created it. That's fine. I have no reason not to believe them. But just like driver's licenses are being faked all over America, you can't tell me that you don't think that those are being faked. So we value them as part of another nation's identification system, but we do not lose sight of the fact that that they can't be trumped by anything we might want to use.

AA: Do you mean that officers don't accept the matrícula as valid ID?

Chief: No, that's not what I said at all. What I said is, they accept it in the process of what they're looking at. If you had a matrícula with your name and your picture, and it exactly matched your name and address, which exactly matched the name and address on an electric bill or whatever, that starts to make sense to an officer and I trust them to get that right. But what we find is a lot of times none of the information matches.

The chief's statement explains why police officers could choose to arrest immigrants who present foreign identification. According to the chief, the department "recognized" matrículas as inferior cards that were less valued than any card issued in the United States. He suggested that accepting the matrícula would require officers to accept all foreign identity documents, an impossibility since officers did 
not know how to evaluate, or even read, documents from every country. Relatedly, the chief expressed doubt about the integrity of foreign identification cards, saying that the cards could be faked and the department did not know how the cards were issued.

The chief also suggested that officers could verify a motorist's identity by triangulating identification cards with other documents such as utility bills. Indeed, this was a popular statement among department administrators. Even if officers were inclined to attempt these procedures (and they were not obligated to try), there were a variety of reasons that they would not work for Latino immigrants. First, not every resident who lives in a dwelling will have utility bills issued in his or her name. Second, because Latino immigrants hail from countries where it is customary to use both their maternal and paternal surnames, in the United States these last names may be hyphenated, they might be separated as middle and last names, or one might be dropped altogether. Describing this issue, Officer Moreno said, "Well, if your name is Juan Gonzalez and it comes back to Juan Gonzalez Mirales, is that really the same? Maybe, maybe not. It depends. It depends."

Sometimes immigrants possessed non-government-issued photo identification that was marketed to immigrants but was not valid. These cards were sold under a variety of names, such as international driver's licenses, international driving documents, and international driver's permits. Some cards appeared to be specific to Tennessee and had the state's name emblazoned on the top. The cards could be purchased at stores and remittance offices and conferred neither driving privileges nor proof of identity because they could be issued under any name.

Indeed, the only documents that the department officially accepted were out of reach for unauthorized Latino residents. Police could cite or arrest Latino motorists who presented a foreign driver's license if the license was not accompanied by a US passport. Conversely, if a driver presented a foreign passport or identification card but no license, the officer arrested on the grounds that this was insufficient proof of identity or cited using the passport as ID. If a driver presented a foreign driver's license and a foreign passport, the officer might still make an arrest if the motorist was a Tennessee resident and not a visitor. Thus, while officers could (and did) accept a variety of documents to establish proof of identity, the only documents for which unauthorized immigrants were eligible could not protect them from arrest.

\section{BALANCING DISCRETION}

In the sections that follow, I detail officers' responses toward driving offenses. Officers weighed multiple considerations - the law, public safety, supervisor preferences, practicality, and their own sense of morality-when deciding how to respond to Latinos who drove outside the law. 
During a ride-along, Patrol Officer Lopez, a bilingual officer on the B shift in the South Precinct, explained to me how he went about making identifications when an individual did not have a driver's license:

They'll tell me straight up-hey, I don't have papers and that's why they get so scared with us. I'm like-you have no papers, do you have any ID on you? If you have some type of ID on you that I can use, I can work with that, but if I can't ID you, then yes, I've got to take you to jail if I don't know who you are. I can accept, me personally, I'll accept certain IDs. I'll accept an out-of-country ID, which you can accept as long as it's valid, you can even drive on a-if I have somebody from Honduras and they have a valid Honduran license that you can verify that it's real, they can drive with it, but if you don't have one... I can take you ... because if I don't know if it's real or not-I can't, I'm not gonna say, "Yeah, you're good," you know, if I don't know that it is good or not. It all depends.

Officer Lopez expressed a willingness to use alternate forms of identification, asking people if they had anything that he could "use." When he said that he, personally, accepted certain IDs, he signaled that he was more accommodating on the ID issue than fellow officers. Officer Lopez was Hispanic and felt comfortable working with different types of identification because he was a fluent Spanish speaker and his previous job frequently put him in contact with the immigrant community.

With this case in mind I asked Officer Lopez what happened when officers misidentified valid identification as false. Officer Lopez responded:

There's no way of proving it-the only reason I know certain IDs are good or not is because I've seen so many of them, I've dealt with enough people that have used them that I can tell certain things. I had a guy give me an ID that said from Mexico but it had all English writing on it. I'm going-it had one of those peel, somebody could just pull the film off is not valid, he probably bought this at the store. A lot of guys say I just bought this-this universal, universal license-over at el Mercado. And I'm like-you know they can't sell that, it's not valid.

Ultimately, Officer Lopez was sympathetic to immigrant workers who crossed the border to support their families and found themselves without a driver's license. However, even he felt obligated to arrest people he could not identify.

\section{WARNINGS}

Of the dozens of traffic stops I observed, officers issued warnings to unlicensed Latino motorists twice. One afternoon, Officer Lopez and I drove slowly through an apartment complex, doing an "apartment check." As we entered the complex, I unbuckled my seat belt, having learned that officers unbuckle when they drive slowly through parking lots, in case they have to get out of the car to give chase. 
"How'd you know to do that?" Lopez asked, with his eyebrow raised. "I know how you roll," I responded, and we burst out laughing.

In the complex, Lopez engaged in four "community contacts." This entailed slowing down and calling out the window to ask people if they lived in the apartment complex and, if so, in which apartment. He could do this because the complex had a trespass warrant on file with the police department; this allowed police to arrest nonresidents who were in the complex and "up to no good." When we saw a middle-aged Latina woman carrying brown grocery bags into her apartment, Lopez hollered a greeting in Spanish as we slowly drove by: "Hola, Señora. How are you?" She looked at Lopez and a flash of recognition crossed her face as she waved. We continued driving and Lopez explained that he had met the woman, Mrs. Martínez, at a community policing event.

Several minutes later we left the apartment complex and Lopez announced that it was time to make some traffic stops. As we were stopped at an intersection Lopez pointed to a black sports utility vehicle in front of us, saying, "Oh, that's an easy stop right there." The car's license plate was covered by a translucent tint. Lopez flashed his lights and sirens, indicating the car should pull over. Lopez approached the driver's side window cautiously, with his fingers gently touching the top of the weapon in his holster. Upon seeing the driver, his demeanor changed immediately-the officer relaxed his posture, smiled, and started chatting amiably with the driver. It was Mrs. Martínez, the same woman we had just seen in the apartment complex. We were practically across the street from her home. After asking about her son, Officer Lopez wagged his finger at her, saying he did not want to see her driving again. However, his tone suggested concern for her well-being rather than concern about the law. When we returned to the car, Lopez said that he understood that people like Mrs. Martínez had to drive out of necessity but that it was against the law. Still, he felt positive about giving Mrs. Martínez a break. "It makes you feel good," he said.

On one occasion, Officer Henderson pulled over a white station wagon with expired tags. After speaking briefly to the driver, a Latina woman in her early thirties, Henderson returned to the patrol car with her driver's license, which was recently expired. He verified that the card had been legally issued, and with no reason to believe that she had done anything else wrong he overlooked the violation and let her go with a warning. He explained, "I don't write those up because people with expired DLs went through the trouble of getting a license. They went down there and filled out the paperwork when the state would give it to them, but now Tennessee decided they're not going to give them licenses? I just think it's messed up." As he saw it, the driver had tried to comply with the law, but the law had changed. Henderson also mentioned that he could confiscate the expired driver's license, but he did not because the card was useful as identification.

While those were the only two warnings I saw for misdemeanor driving offenses, other officers described letting some unlicensed drivers go with warnings. 
For example, when discussing stats over a meal break, Officer Neal said that sometimes he did not even bother issuing state citations because there was no way to know if he was issuing it under the correct name. Officer Thompson looked surprised by this admission, and Neal explained. "Sometimes I cut them loose. What are you going to do? People are going to drive. They need to drive to work."

While numerous officers expressed some level of sympathy or understanding regarding unauthorized immigrants' ineligibility for driver's licenses, most were unwilling to simply overlook misdemeanor driving offenses. In the overwhelming majority of interactions, officers chose between the more legalistic options of issuing misdemeanor state citations and making arrests.

\section{MISDEMEANOR STATE CITATIONS}

Although officers could always arrest unlicensed drivers, they did not always do so. Tennessee's "cite and release" statute directs officers to issue misdemeanor state citations, instead of making physical arrests, whenever suspected misdemeanants "qualify" for one. Indeed, officers used a variety of documents to establish motorists' identity, including foreign driver's licenses, identification cards, and passports, and even non-government-issued photo identification (though far more reluctantly).

Sometimes officers issued misdemeanor state citations because of their positive evaluations of immigrants' good character. Officers described Latino residents as hard workers who were generally law abiding and devoted to their families. "These are not bad guys. They're just on their way home from work. How do you arrest someone for feeding their family? The only way you don't give them a misdemeanor citation is if they've failed to appear a bunch of times but they're going to do it again," said Officer Clark. Issuing state citations made some officers feel altruistic; they felt they were doing motorists a favor. Latino motorists who responded appreciatively when receiving citations reinforced these perceptions.

Officer Phillips and I parked in the parking lot of an old gas station that was no longer in business. I was riding along with Officer Phillips in his patrol car, and he was schooling me on the art of making vehicle stops. We were at his go-to spot, a reliable location, he said, to catch people rolling through stop signs so he could pull them over. We had not been there for two minutes when a red late-model Honda with tinted windows cut through the parking lot to make a right turn, cutting ahead of the line of cars waiting at the four-way stop.

"Here we go!" Officer Phillips said, in a satisfied voice. He sprang into action, quickly pulling up behind the car and flashing the patrol car's lights.

The Honda stopped, never making it out of the parking lot. The driver was a young man who appeared to be about twenty. He wore blue jeans, a maroon striped polo shirt, and aviator sunglasses. With his chocolate brown skin and dark brown spiky hair, I guessed he was Latino. When Officer Phillips requested his 
license, the young man handed over a Mexican driver's license, issued from the state of Chihuahua. Upon seeing that the driver's license was foreign, Officer Phillips asked for the young man's passport. Shaking his head apologetically, the young man explained he did not have his passport with him.

Officer Phillips returned to the patrol with the driver's license in hand. He inspected it closely, then held it up in the air, as if trying to see through it. He ran his finger along the front and back of the card to check for blemishes. Shrugging, he handed it to me. Unfamiliar with Mexican driver's licenses, he wanted my opinion.

"It's real, isn't it? It has holograms," Officer Phillips said, as I handled the card. As a third-generation Mexican American, I had no idea what a Mexican driver's license from the state of Chihuahua looked like, but I doubted it looked like this. This card said "Chihuahua" in an unprofessional bubbly font. The back of the card had a spot for a signature, but instead of a signature, the young man's name was printed in a large cursive font. I was not willing to express my skepticism, so I told Officer Phillips that the card looked official, agreeing that the holograms were a mark of the card's veracity.

Persuaded that the card was real, Officer Phillips was still not sure how to proceed. Technically, foreign visitors may use their country's driver's licenses while visiting, but only when the license is accompanied by a passport. Phillips reached into his breast pocket for his cell phone and dialed his sergeant for clarification. He explained the situation, asking if he could accept the young man's driver's license. Phillips got his answer and hung up. He told me that without an accompanying passport the driver's license was not valid. Technically, this young man was driving without a license, a misdemeanor in Tennessee. He told me he was going to issue the young man a state citation for driving without a license, as well as a ticket for illegally cutting through the parking lot.

A misdemeanor state citation is technically a noncustodial arrest in which the suspected misdemeanant is given a paper citation and released, rather than taken into custody and booked at the county jail. According to the statute, police officers should cite suspected misdemeanants as long as they have provided reasonable proof of their identity and the officer does not have reason to believe that the suspected misdemeanant will fail to appear for court. People who cannot or will not produce "satisfactory" evidence of identification are ineligible for misdemeanor state citations and are subject to arrest.

"Shit," said Phillips, looking out the window. In the minutes that we had been sitting in the car, the sky had opened up and it was pouring. Officer Phillips got out and ran to the driver's side of the Honda, gesturing for the young man to get out of his car and follow. The young man obliged, following Phillips back to the patrol car and sliding into the back seat as Phillips held the back door open for him. Phillips got back in the car and explained that this was a better alternative than both of them standing in the rain getting wet. 
This alarmed me. I was uncomfortable with this young man sitting in the back seat of a patrol car, merely for the officer's convenience. The officer's demeanor was pleasant, but the practice seemed punitive and intimidating.

"How long have you been in Nashville?" asked Officer Phillips as he looked through a pile of documents contained in a black aluminum clipboard with a storage compartment.

"Uh-My dad has a business, but like-since I'm fifteen," responded the young man politely, in slightly accented English.

Officer Phillips raised his eyebrow, telling the young man that he had been in Tennessee long enough to be a resident. The rules for international visitors and immigrant residents are different. Technically, foreign driver's licenses are valid for visitors, but anyone who moves to Tennessee is supposed to obtain a state driver's license within thirty days of establishing residency. Officer Phillips told the young man to get a Tennessee license and that if he planned to continue using the Mexican driver's license he should carry his passport as well.

The young man nodded. "I didn't know," he said.

"I can't guarantee that it will work, but it should," said Officer Phillips.

Officer Phillips asked a series of questions so that he could fill out the documents on his clipboard. He took the young man's fingerprints for the citation and explained he was issuing a state citation for driving without a license and a ticket for cutting through the parking lot.

"You have forty-five days to take care of this ticket, okay? It's not going to be that much."

The young man nodded and apologized, explaining that he had not known that cutting through a parking lot was wrong. Phillips was about to hand the young man the ticket and citation, but he paused, explaining that it was "very important" that young man goes to court when he was supposed to. He could not ignore these violations. Phillips told him that the court date was in thirty days.

"Where will you be in thirty days?" Phillips asked the young man.

"In court."

“That's right. Because you don't want a warrant."

The man nodded. Phillips explained what would happen next. "You don't have a license, so you shouldn't be driving, but after I leave, I'm not going to be watching," he said. "One sec-I'm going to drive you to your car." Phillips drove the patrol car and stopped next to the Honda, telling the young man he was free to go. The man was momentarily confused, not sure where to open the door since there was no interior door handle. He noticed that Phillips had rolled down the window and reached through it to open the door using the outside handle. The young man thanked him repeatedly. He stood there, watching us drive away.

"Can you believe that? He said thank you," Phillips said, in surprise.

In fact, the young man was so polite that later in the shift Phillips expressed some regret about having issued him a state citation. He had been courteous. He had a 
foreign license and a visa. Perhaps he should have gotten a warning. Phillips shrugged off this idea and attributed his own behavior to the department's emphasis on productivity, saying that at least he had gotten a (noncustodial) arrest out of the stop.

Aside from officers' moral evaluations, some issued misdemeanor state citations for practical reasons. While a state citation could be dispensed in fifteen to twenty minutes, booking someone took an officer off patrol for hours. This could be a deterrent. "Sometimes, I don't think officers want to go through the booking process because it takes them off the street for a long time. It's easier to write someone a citation than it is to book somebody," Moreno explained.

One afternoon, as Officer Jones and I were en route to a call, we saw a car swerve erratically into another lane. Jones had not planned to make any more stops that shift; it was a busy evening. Still, out of concern that the driver might be intoxicated, Jones pulled the car over. The driver, a Latino man who appeared to be in his early twenties, explained that he had dropped something in the passenger seat and that he had swerved when he tried to retrieve it. He did not have a driver's license and handed Officer Jones a card emblazoned with the words "International Driver's Document" (IDD). The card looked official, but small print on the back stated it was not valid for identification. IDD applicants did not have to present any proof of their identity when applying for the card; it could be purchased at a local store under any name. Jones looked pensive as he twirled the card with his fingers and tapped it on the steering wheel, saying that he thought he would have to "take the driver in" because the card was not sufficient proof of identity. Unsure, he decided to call his supervisor and explain the situation. His supervisor's response came quickly and decisively: "State citation, okay." I thought it was ironic that Jones used the IDD, which listed the motorist's name and address, to fill out the information on the misdemeanor state citation.

One afternoon Officer Henderson and I responded to a minor traffic accident. A middle-aged white man who had failed to yield clipped the bumper of a Latino motorist at a busy intersection. After Henderson asked both motorists for driver's licenses, the white motorist produced a Tennessee license and the Latino gave him a consular identification card, saying it was all he had. Henderson returned to the car and wrote the young Latino a state citation, saying that he felt bad about it because the accident was not that driver's fault. Thus, in the end, the white motorist left with an admonition to be more careful, while the Latino motorist left with a damaged bumper and a state citation. Issuing the citation bothered Officer Henderson enough that two hours later he recounted the story to another officer, saying that he felt bad. The officer interrupted him: "Be honest, will it keep you up at night?" The officer paused and snorted. "No," he responded firmly.

During a meal break Officer Hawk indicated a general willingness to make custodial arrests for driver's license violations, saying, “The law is the law," but he also mentioned other incentives: "In the time it takes to make one arrest, I could make three misdemeanor citations." As he made this statement he held up his hand, 
rubbing his thumb and index finger together-he was making the sign for money. Officer Thompson looked surprised: "You get court for that? I never get called in for that." Hawk laughed and shrugged.

Sometimes officers believed that driver's license arrests were not worth making because of the severity of the offense. For example, Officer Thompson told me he used to regularly arrest people for driving without a license, but "now, I do mostly state citations." "Why'd you change?” I asked. "I just ... I didn't feel like I was making a difference. Neal has opened my eyes to things. He's taught me there's a lot going on in South. It's not just burglaries. There's guns and dope. Traffic, it's not really a serious offense. I'd rather be getting guns and drugs off the street."

Thus misdemeanor state citations were often described as a compromise between ignoring an offense and being unnecessarily punitive. Still, misdemeanor state citations are more regulatory than their rhetoric suggested: they are still a criminal sanction. Three weeks after one receives a state citation, one must undergo a lengthy booking process at the Davidson County Courthouse-the procedures of which include entering the offender's fingerprints and mug shot into a county database and imposing steep fines. For those who appear, the process is inconvenient, costly, and stressful. The courthouse is downtown, far from Nashville's Latino immigrant neighborhoods. Getting there requires driving, perhaps without a license. The courthouse is across the street from the county jail where the sheriff's office screens inmates for immigration violations. Citations booking is also expensive, requiring individuals to miss a day of work and pay fines that amount to several hundred dollars.

For those who do not go to court on their booking date, consequences are severe. Failing to appear results in an immediate arrest warrant, to be executed by the police department's warrant division or upon the department's next interaction with the individual in question. Once a person has a warrant, the officer must and will arrest the individual, regardless of the initial offense. That is, it does not matter why the warrant was issued or if the officer encounters the person with warrants on a service call; arresting people with warrants is a police priority. People with warrants are presumed to be criminals who must be taken off the streets. As a result, misdemeanor state citations are also a path to a subsequent physical arrest.

\section{SERVING WARRANTS}

One night during a lull on patrol, Officer Brown and Officer Lopez decided that they should try to serve a warrant to be proactive. I was riding with Officer Brown, but Lopez met us at the apartment complex where they were going to try to serve the warrant. Lopez checked the warrants list on the dashboard computer. A number of residents in the apartment complex had outstanding warrants, but many of the warrants were old. Brown and Lopez decided that they were most likely to find 
the newest person on the list because other officers had probably already tried to serve the older warrants. After they chose someone to look for, we got out of the car to find the apartment. After we had walked a few yards, Brown stopped and conferred with Lopez.

"Shit. Do you remember the name?" he asked.

“Errr. Hernandez. Jimenez?” Lopez responded, shaking his head and laughing.

"Gonzalez. Rodriguez," Brown responded. He popped back into the patrol car to check the name. "Martinez!" he called out.

They approached the apartment door, and Brown and Lopez stood shoulder to shoulder in front of it. I stood a few steps behind them. Brown knocked. A Latina woman turned the knob and peered cautiously around the door. She opened it a little wider when she saw the uniformed officers.

Lopez took the lead, extending a formal greeting and asking, in Spanish, if he could speak to Señor Martinez.

She shook her head apologetically and politely responded that he was not there.

Lopez asked some follow-up questions. His tone was friendly and conversational. Did she know Martinez? When was the last time he had been home? When might he return? She told us that she did not know him but she knew his girlfriend, and they had moved apartments several weeks ago. She gestured to unpacked boxes in the apartment and explained that she had just moved in. She apologized for the mess.

"Don't be embarrassed," Lopez responded, waving off her concern about the state of her apartment. He continued asking about Mr. Martinez, and the woman responded, "Seriously. He's not here. He doesn't live here."

"Okay, no problem," Lopez responded. "Would you mind if I take a look at your ID to verify your name and make sure that your last names don't match, for example?"

She walked over to her purse and returned, handing him a passport. Their names were different.

Lopez thanked the woman, wishing her a good day, and we turned to leave. Lopez left in a perfectly good mood, willing to accept the woman's explanation. In contrast, Officer Brown was agitated.

"She's flat out lying," he said bitterly as he returned to his patrol car and slammed the door in a huff.

Lopez and I looked at each other with raised eyebrows, surprised by Brown's displeasure.

\section{ARRESTS}

In 2007, only 8 percent of all traffic stops resulted in arrests; however, stops made on Latino drivers led to arrests 29 percent of the time. ${ }^{33}$ While the department 
encouraged officers to make state citations for misdemeanor offenses, including driver's license offenses, officers could also choose to make physical arrests. These arrests were driven by state law (unauthorized immigrants' ineligibility for state-issued driver's licenses and identification cards), institutional practices (the department's prioritization of investigative vehicle stops), and individual officer discretion. The confluence of these factors compelled officers to make physical arrests, even as they acknowledged that driver's license offenses were not serious. "You make the effort to look them up in the system, but they're not there. You don't want to arrest someone for no DL but sometimes you have to," explained Officer Brown.

On a lunch break at Taco Bell, a group of officers began discussing their stats. Between bites, Officer Calvin mentioned that he was "tired" of "no DLs." I clarified, asking him if he was tired of arresting people for driver's license violations, and Calvin shook his head. "No, I'm tired of not arresting them. I'm tired of state citations for no DL. If it's illegal, we should arrest people." Calvin went on to say that issuing too many state citations was bad for his stats. Arrests looked better, and when they resulted in getting called to court he could earn overtime. Officer Brown, in an attempt to be helpful, pointed out that he could make arrests instead of issuing state citations: "Just write 'No ID, insufficient proof of ID." Officer Hendrick chimed in, "But if we arrested everyone who was driving without a license, there wouldn't be people left on the streets to patrol!" The table exploded in laughter.

While Officer Hendrick quickly changed the subject with his well-timed joke, I found the conversation between Officer Calvin and Officer Brown to be very revealing. Officer Calvin complained about writing citations for driver's license violations because he felt that arrests were more richly compensated. Here the officers were discussing, not the severity of the offense or whether civilians "deserved" to be punished, but how their decisions aligned with the department's incentive structure. Trying to solve his problem, Officer Brown told him how he could justify making arrests instead of issuing state citations.

Indeed, officers could invoke a number of justifications to assert that Latino misdemeanants were ineligible for citations and had to be taken into physical custody. An officer might arrest an unlicensed motorist because he or she had outstanding arrest warrants, likely issued after the motorist had missed a court date for a misdemeanor state citation. An officer could arrest a person with a history of driving offenses, stating that the motorist was ineligible for a state citation because the offense was "likely to continue." An officer might assert that a suspected misdemeanant had to be taken to jail because he or she would not appear for court and this would jeopardize the officer's prosecution of the offense. This is what one officer asserted on his arrest report after booking a woman involved in a car accident: "The defendant was involved in a car crash. The defendant identified herself 
as the driver. The defendant states she has lived in Nashville for over two years and have $[s i c]$ never obtained a driver's license. The defendant could not show proper ID, and it is reasonable that prosecution would be jepordized [sic] if not taken into physical custody." Note that the officer claimed, not that the woman failed to present identification, but that she could not show "proper ID." Indeed, officers might summarily reject any identification presented to them. For example, after an officer conducted an investigative stop because a car was driving through a deserted business park late one night, the officer arrested the driver for driving without a license, even though the driver presented a consular identification card. On the arrest report the officer wrote, "Defendant has a Mexico ID, but no DL."

An analysis of arrest reports shows an uptick of characteristics related to "foreignness" and "immigration status" after the sheriff's implementation of the $287(\mathrm{~g})$ program. ${ }^{34}$ For example, some arrest reports refer specifically to Latinos' "immigration status," indicating either that immigrants confessed to being "illegal aliens" or that the officer suspected them to be. According to police administrators, these statements were not supposed to be in charging documents for local criminal violations, but the fact that they are suggests that some officers believed that immigration status was relevant. Thus, while local police were not supposed to arrest people because they were undocumented, officers' virtually unfettered discretion to arrest unlicensed drivers provided plenty of opportunities for officers to act on their prejudices.

\section{RACE, PROFILING, AND POLICING}

When I tell people I have spent many hours riding with police officers, they inevitably want to know if the police racially profile. In Nashville, as in most US cities, racial minorities are more likely than whites to be stopped by the police. In addition, decades of studies show that police stop and search black and Latino motorists at much higher rates than white drivers. ${ }^{35}$ The source of these racial disparities engenders intense debate among researchers, agencies, and the general public. For example, police agencies argue that racial disparities are at an artifact of geography: minorities are more likely to live in high-crime areas that are heavily patrolled.

Courts have consistently found that police stops are discriminatory only if the officer articulates racial discrimination. That is, the officer would literally have to announce that the motorist's race, and nothing else, triggered the stop. Obviously, no officer would ever admit to this. As I discussed in this chapter, officers can use a number of legal justifications to make stops that are perfectly acceptable by contemporary legal standards. Thus, as long as the officer articulates a legal justification for making the stop that does not invoke race, the officer is not racially profiling according to the legal definition. 
Obviously, I never heard an officer articulate racially discriminatory intent. It is highly unlikely an officer would express such intent with a Mexican American woman riding as a passenger. This is, of course, a very narrow standard for racially biased policing. In fact, the preoccupation with identifying racism in individual officers ignores how deeply racism is embedded in laws, institutions, and routinized practices. As I argued in chapter 1, American immigration laws have a history of racial exclusion that continues to this day. In chapter 2, I argued that state laws that punish illegality are similarly racially motivated, even though these laws are couched in a color-blind rhetoric. In this chapter I show how institutionalized police practices ensure that police punish illegality just by doing their jobs. Police do not need to want to target Latino immigrants to cite and arrest them. They need only behave exactly as they are supposed to, making large numbers of stops for minor technical infractions. Unauthorized immigrants, the majority of whom are Latino, are outside the law by design.

In Southeast Nashville, officers came into contact with Latinos every day. Much of this contact was involuntary, occurring after an officer stopped a resident's car for a minor traffic violation or pounded on the door to serve a warrant. Through their repeated interactions with Latino residents, police came to associate particular circumstances - such as driving without a license, not having state-issued identification, furnishing a consular identification card, and speaking Spanish-with foreignness and "illegality." I observed these types of assumptions in action when an officer stopped a young Latino man near a gas station for having expired tags. Speaking in lightly accented English, the man apologized for not having a license, saying that he had just moved to Nashville from California. He showed the officer several credit cards and the car registration in his name. "I don't want no trouble, officer," he said, apologetically. The officer decided to give him a state citation. Without asking where the man was born, the officer began writing "M-E-X" in the designated space. Only as an afterthought did he pause to confirm. "Born in Mexico?" the officer asked. "Orange County, sir," the man responded, naming a location in Southern California.

Officers would not necessarily treat Latino immigrants that they assumed to be undocumented more punitively than they would other residents. Officially, the department did not allow officers to enforce immigration laws. To the department, immigrant illegality was a professional problem that could be addressed via community outreach (see chapter 4 ). Indeed, when officers voiced concerns about Latino immigrants in my presence, their concerns were not about immigration law but about how inconvenient it was for officers that many did not have stateissued ID. Of course, even the most sympathetic officer would cite and arrest undocumented immigrants for license violations. It was part of the job. Officers had discretion, but they did not have complete freedom to ignore an entire category of violations. Even if they did, ignoring license violations would be bad for their 
stats. On the other hand, officers who wanted to punish suspected undocumented immigrants could do so legally by articulating a number of justifications: The officer was not "comfortable" with the motorist's ID. The officer believed the motorist would commit the offense again. The officer believed the motorist would fail to appear for his or her court date. These legal justifications were intricately connected to immigration status, as the officer might use an immigrant's suspected illegality as justification for the belief that the motorist would fail to appear. Moreover, the department chose to give officers wide latitude regarding their identification standards. The department could decide that passports, consular identification cards, and international IDs were "valid" forms of identification. The fact that they did not disproportionately burdened Mexican and Central American immigrants, the groups who were most likely to be out of status.

Patrol officers made stops for technical violations because it was a bureaucratic priority. While their tactics might put officers into contact with all residents, they subjected only some residents to increased levels of scrutiny. Thus, through their implementation of the MNPD's policing priorities, officers subjected Latino residents to lengthy stops because writing a citation and deciding to make an arrest took longer than issuing a warning. As Latino motorists awaited their fate, they sat idly on the side of the road, on display for all passing motorists to see. These intrusive encounters sent a powerful message about Latino residents' place in the racial hierarchy, marking Latinos as less than full citizens in the polity. 